\title{
РЕОЛОГІЧНІ ДОСЛІДЖЕННЯ ПАСТИ ЦЕОЛІТУ ПРИРОДНОГО 3 КРЕМНІЮ дІоксидом
}

\author{
(C) В. Д. Рибачук, О. А. Рубан \\ Національний фрармацевтичний університет, Харків \\ v.d.rybachuk@gmail.com
}

\begin{abstract}
Мета роботи. Вивчити реологічні властивості пасти цеоліту природного (кліноптилоліту) з кремнію діоксидом як загущувачем для вибору їх оптимальних концентрацій.

Матеріали і методи. Об'єктами дослідження були модельні композиції паст, що містили в якості діючої речовини порошок цеоліту природного (кліноптилоліт) у концентраціях 15 \%, 20 \%, 25 \% та 30 \%, а в якості загущувача кремнію діоксид у концентраціях 5,0 \%, 6,0 \%, 7,0 \% та 8,0 \%. Визначення реологічних параметрів проводили при температурі $(20 \pm 2){ }^{\circ} \mathrm{C}$ на віскозиметрі MYR VR3000 (Іспанія), робота якого основана на методі Брукфельда. Дослідження проводили у діапазоні швидкості зсуву від $1 \mathrm{c}^{-1}$ до $200 \mathrm{c}^{-1}$ з використанням коаксіальних циліндрів. Результати й обговорення. Визначено, що досліджені зразки належать до тиксотропно-структурованих псевдопластичних систем зі структурою коагуляційного типу. Цеоліт природний (кліноптилоліт) разом із кремнію діоксидом чинять структуруючий вплив на дисперсну систему, а їх оптимальні концентрації, що забезпечують достатнє структуроутворення, становлять 25-30 \% та 7-8 \% відповідно.

Висновок. Вивчено реологічні властивості пасти цеоліту природного (кліноптилоліту) з кремнію діоксидом як загущувачем та обрані їх оптимальні структуроутворюючі концентрації. Отримані результати будуть використані при розробці складу паст ентеросорбентів із цеолітом природним.
\end{abstract}

Ключові слова: реологічні властивості; цеоліт природний; кліноптилоліт; кремнію діоксид; паста.

Вступ. Фармацевтичні препарати у фрормі паст протягом багатьох років успішно використовуються у фрармацевтичній практиці. Характерною рисою даної групи лікарських фрорм є наявність дисперсних структур, тип яких визначає реологічні властивості готового препарату. Властивості паст залежать від низки чинників, найважливішими з яких є концентрація твердої фрази та природа дисперсійного середовища [1].

Реологічні характеристики дисперсних матеріалів тісно пов'язані з характеристиками геометричної конфрігурації та гранулометричного розподілу їх частинок. Велику теоретичну та практичну цінність мають залежності реологічних параметрів (меж зсуву та критичних в'язкостей) від вмісту та концентрації компонентів дисперсної фрази, оскільки вони дозволяють встановити кількісний взаємозв'язок між поверхневими та геометричними властивостями дисперсних частинок та характером течії їх суспензій [2-6].

Всебічне вивчення реологічних характеристик являє собою як теоретичний, так і практичний інтерес, оскільки вони можуть бути ефективним та об'єктивним критерієм контролю їх якості на етапі створення, виробництва, зберігання та використання [7-9].

Ця праця є продовженням циклу публікацій, присвячених дослідженню впливу виду та концентрації загущувачів на реологічні властивості м'яких лікар- ських форм із цеолітом природним (кліноптилолітом), зокрема, пероральних паст з ентеросорбтивною активністю [10].

Мета роботи. Вивчення реологічних властивостей пасти цеоліту природного (кліноптилоліту) з кремнію діоксидом як загущувачем для вибору їх оптимальних концентрацій.

Матеріали і методи. Об'єктами дослідження були модельні композиції паст, що містили в якості діючої речовини порошок цеоліту природного (кліноптилоліт) в концентраціях $15 \%, 20 \%, 25 \%$ та $30 \%$, а в якості загущувача - кремнію діоксид у концентраціях 5,0 \%, 6,0 \%, 7,0 \% та 8,0 \%. Концентрації цеоліту природного (кліноптилоліту) та кремнію діоксиду обирали з огляду на властивості пасти як лікарської форми та результатів фрармакологічних досліджень із вивчення ентеросорбційних властивостей цеоліту і $\epsilon$ прийнятними з фармакотерапевтичної та технологічної точок зору $[1,7,11]$. Приготування випробовуваних зразків відбувалось шляхом додавання відповідних кількостей кремнію діоксиду та цеоліту природного (кліноптилоліту) при перемішуванні до води очищеної 3 наступною гомогенізацією та вакуумуванням отриманої дисперсії.

Визначення реологічних параметрів проводили на віскозиметрі MYR VR3000 (Іспанія), робота якого

ISSN 2312-0967. Pharmaceutical review. 2018. № 1 
Фармацевтична технологія, біофармація, гомеопатія Pharmaceutical technology, biopharmacy, homeopathy

основана на методі Брукоельда та дозволяє визначати структурно-механічні властивості у діапазоні швидкостей зсуву від $1 \mathrm{c}^{-1}$ до $200 \mathrm{c}^{-1} 3$ використанням коаксіальних циліндрів. Методика визначення структурної в'язкості полягає в наступному: наважку зразка поміщали в камеру та занурювали в неї обраний шпиндель, який приводили в обертання. На електронному дисплеї приладу фріксували значення в'язкості, швидкості зсуву та напруги зсуву, які виводяться автоматично. Реологічні дослідження проводили при температурі $(20 \pm 2)^{\circ} \mathrm{C}$, яка відповідає передбачуваній температурі зберігання та проведення технологічного процесу виробництва пасти [3].

Результати й обговорення. Під час експериментальних досліджень ми насамперед вивчали вплив наявності цеоліту в складі пасти на динамічну в'язкість основи. Дослідження властивостей в'язкості дає можливість оцінити тиксотропність систем, розглянути характер петель гістерезису в разі їх прояву в системах при десрормаційних навантаженнях і в цілому. Досліджували зразки, що містили кремнію діоксид у різних концентраціях та цеоліт природний (кліноптиоліт) у кількості 25 \% до загальної маси зразка. Значення динамічної в'язкості фріксували при швидкості зсуву $D_{r}=5,0 \mathrm{c}^{-1}$. За отриманими експериментальними даними будували криві залежності значень в'язкості від концентрації кремнію діоксиду (рис. 1). Отримані результати показали, що в'язкість дисперсій залежить як від концентрації кремнію діоксину, так і від наявності у складі композиції цеоліту. Особливо помітний вплив на даний реологічний показник показала присутність цеоліту природного (кліноптилоліту) у складі систем з вмістом кремнію діоксиду 6-7 \%. Залежність значень досліджуваного параметра від концентрації дисперсної фрази пояснюється збільшенням кількості міжчастинкових контактів в одиниці об'єму дисперсії та зміцненням системи в цілому при підвищенні вмісту твердої фрази.

Оскільки суттєвий вплив на реологічну поведінку мінеральних дисперсій має об'ємна концентрація часток твердої фрази, ми для більш детального вивчення впливу концентрації цеоліту природного (кліноптилоліту) на динамічну в'язкість дисперсій вивчали експериментальні зразки з різним вмістом обох зазначених компонентів. Отримані дані (рис. 2) показали, що при вмісті цеоліту в системі менше 20 \% його вплив на фрормування в'язкості незначний. $3 і$ збільшенням об'ємного вмісту цеоліту природного (кліноптилоліту) до деякого критичного значення відбувається зміна властивостей системи, що є ознакою фрормування внутрішньої структури системи. Графічно про це свідчить «стрибок» значень динамічної в'язкості при переході концентрацій в межах 20-25 \% і вище.

Одним з обов'язкових вимог при дослідженні реологічних властивостей м'яких лікарських фрорм $€$ вивчення їх повних реограм плину [9]. Для цього фріксували залежність значень напруги зсуву $\left(\tau_{r}\right)$ від швидкостей зсуву $\left(D_{r}\right)$ методом безперервно зростаючого руйнування структури при зміні швидкості обертання шпинделя від 1 до 200 об/хв, фріксуючи постійну напругу зсуву при максимальному числі обертів, і при подальшому зменшенні числа обертів у зворотному напрямку. Отримані результати представлено графрічно на рисунках 3, 4.

Аналіз отриманих результатів свідчить, що реологічна поведінка досліджуваних зразків має всі ознаки висококонцентрованих дисперсних систем зі структурою коагуляційного типу. Ознакою цього є нелінійний характер реологічних кривих та неповна відтворюваність реологічної поведінки дисперсій за динамічних умов. Це виражається у появі гістерезисної петлі,

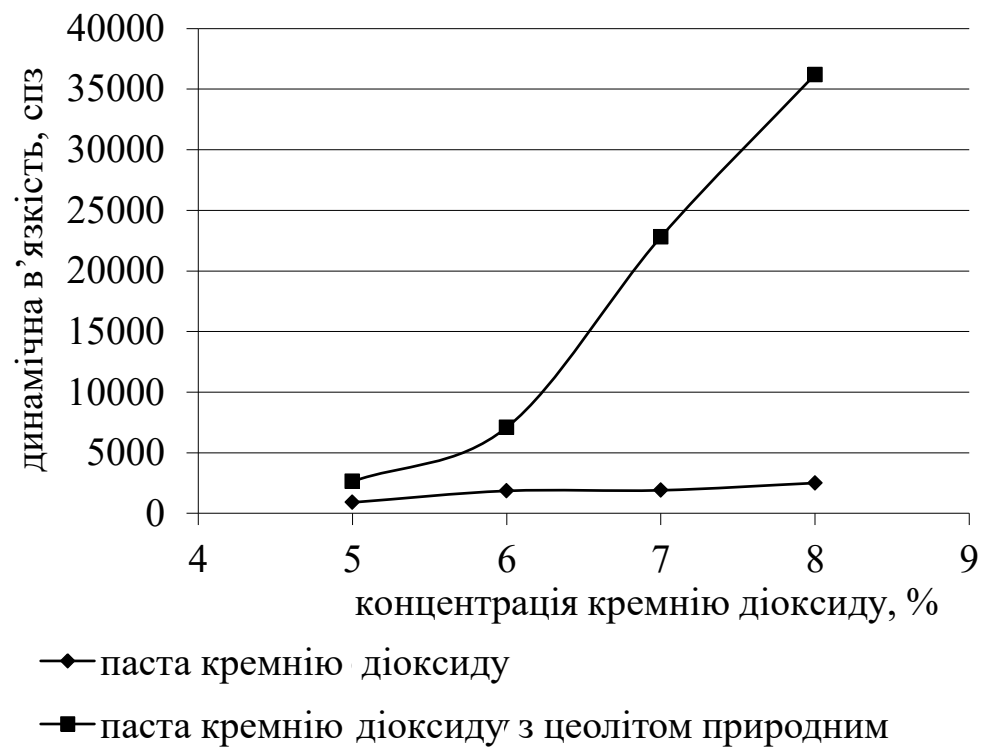

Рис. 1. Залежність динамічної в'язкості паст від концентрації кремнію діоксиду та присутності цеоліту природного.

ISSN 2312-0967. Фармацевтичний часопис. 2018. № 1 
Фармацевтична технологія, біофармація, гомеопатія Pharmaceutical technology, biopharmacy, homeopathy

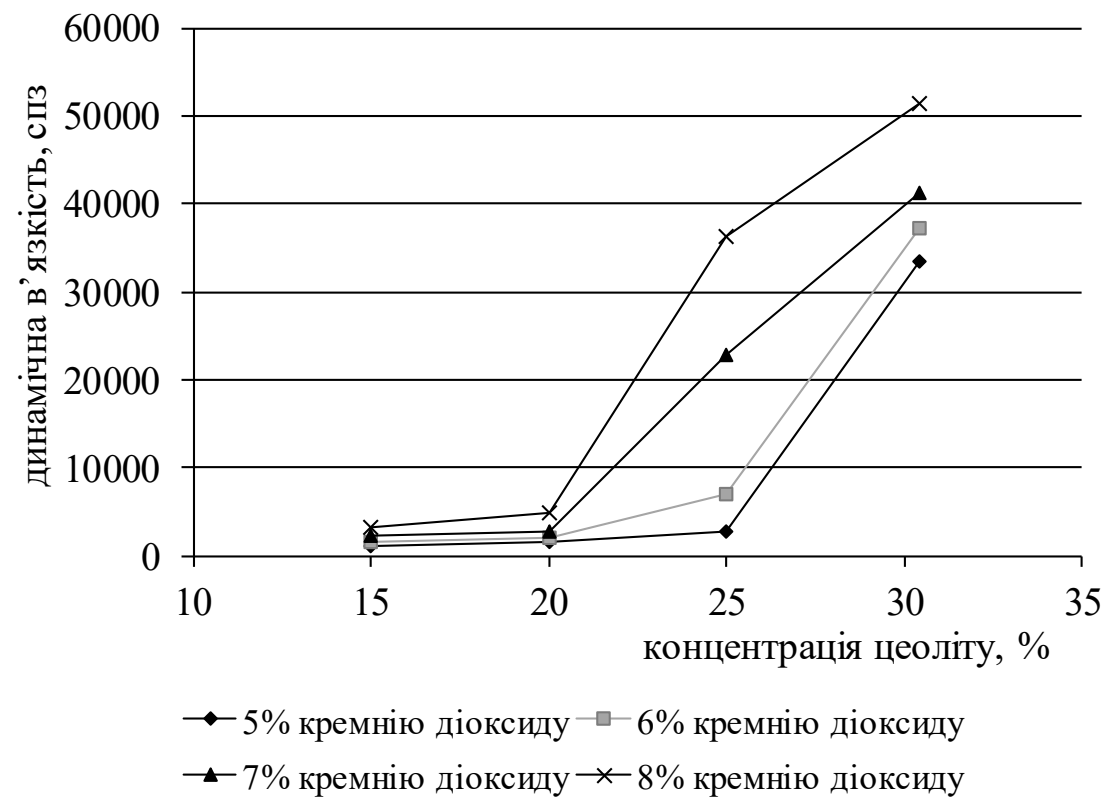

Рис. 2. Вплив концентрації цеоліту природного на динамічну в'язкість паст із різним вмістом кремнію діоксиду.

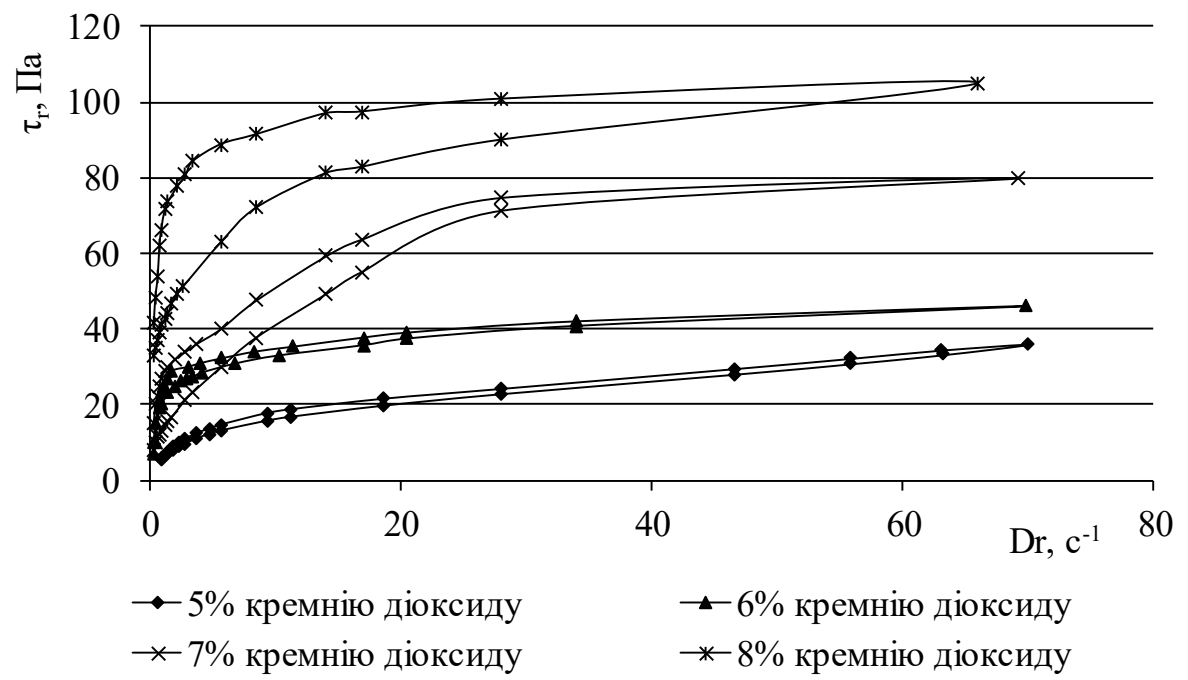

Рис. 3. Повні реограми плину паст із різним вмістом кремнію діоксиду.

розміри якої зі збільшенням вмісту кремнію діоксиду та цеоліту (кліноптилоліту) в системі помітно зростають, а реологічні криві зміщуються в область вищих напруг зсуву.

На рисунку 3 наведено повні реограми плину зразків із постійним вмістом цеоліту на рівні $25 \%$ та різних концентрацій кремнію діоксиду. Як бачимо, підвищення концентрації кремнію діоксиду призводить до помітного впливу на реологічну поведінку зразків. В області концентрацій кремнію діоксиду 5-6 \% зразки поводяться як слабкоструктуровані системи. Початок течії починається вже за мінімальних значень швидкості та напруги зсуву, а коагуляційна структура характеризується більш високим рівнем відтворюваності. За подальшого збільшення концентрації кремнію діоксиду до 7 та 8 \% відбувається різке наростан- ня міцності структурної сітки, зростає загальмованість відтворення структури системи, про що свідчить площа між висхідними та низхідними кривими гістерезисної петлі.

Подібну залежність спостерігали також при зміні концентрації цеоліту природного (кліноптилоліту) у складі зразків. Наведені на рисунку 4 повні реограми зразків з 7 \% вмістом кремнію діоксиду та різною концентрацією цеоліту показали, що цеоліт чинить структуруючий вплив на дисперсну систему, а суттєве збільшення тиксотропності відбувається при використанні його в концентрації 25-30 \%.

На рисунку 5 показана залежність ефективної в'язкості мінеральних дисперсій від швидкості зсуву. Як бачимо, підвищення концентрації цеоліту від 15 до 30 \% призводить до збільшення початкового зна-

ISSN 2312-0967. Pharmaceutical review. 2018. № 1 
Фармацевтична технологія, біофармація, гомеопатія Pharmaceutical technology, biopharmacy, homeopathy

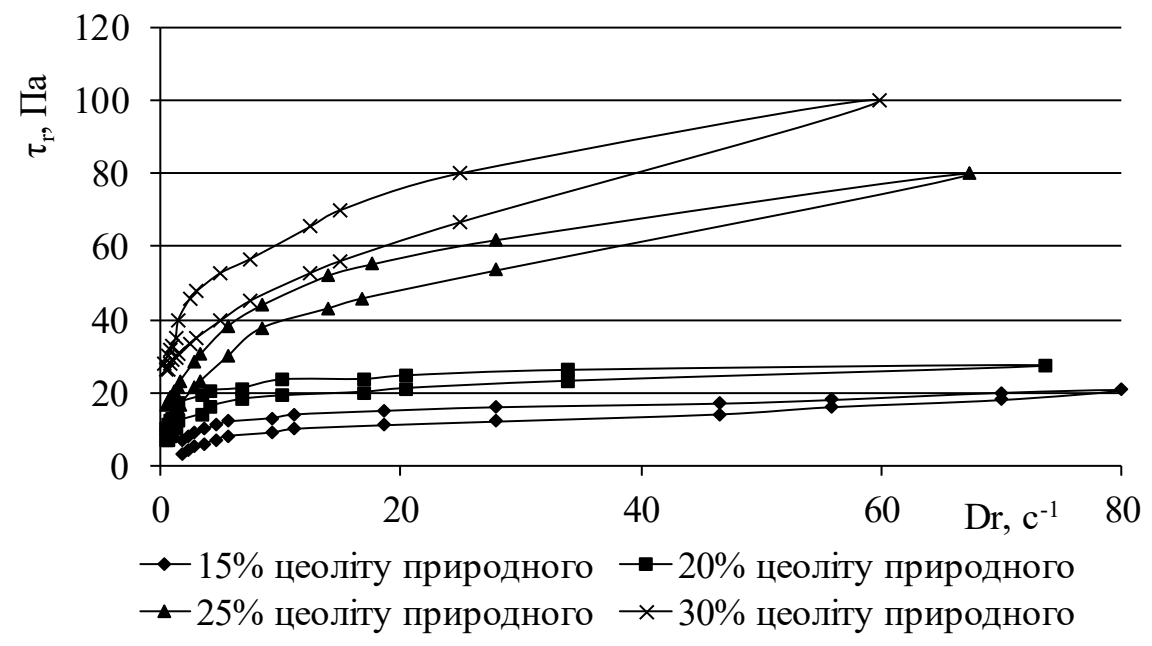

Рис. 4. Повні реограми плину зразків із різним вмістом цеоліту природного.

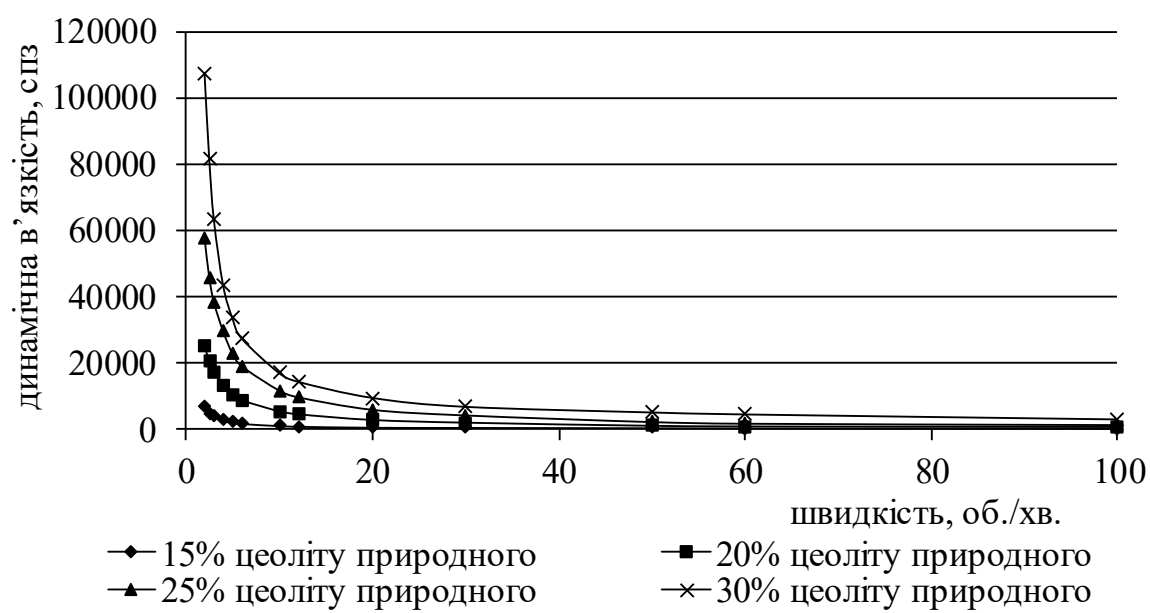

Рис. 5. Вплив швидкості зсуву на динамічну вязкість зразків із різним вмістом цеоліту природного.

чення ефективної в'язкості більш ніж в 5 разів, що також підтверджує явно виражений структуруючий вплив цеоліту. Руйнування дисперсної структури супроводжується різким зниженням ефективної в'язкості дисперсної системи у порівняно вузькому інтервалі швидкостей.

Характер наведених на рисунках 4 та 5 реологічних кривих свідчить про те, що модельні зразки пасти в дослідженому інтервалі значень належать до типових псевдопластичних систем.
Висновки. Вивченно реологічні властивості пасти цеоліту природного з кремнію діоксидом. Доведено, що дослідні зразки пасти належать до тиксотропноструктурованих псевдопластичних систем зі структурою коагуляційного типу. Визначені оптимальні концентрації цеоліту природного (кліноптилоліту) та кремнію діоксиду, що забезпечують структуруючий вплив на дисперсні системи, на рівні 25-30 \% та 7-8 \% відповідно. Отримані результати будуть використані при розробці складу паст ентеросорбентів із цеолітом природним.

ISSN 2312-0967. Фармацевтичний часопис. 2018. № 1 


\title{
РЕОЛОГИЧЕСКИЕ ИССЛЕДОВАНИЯ ПАСТЫ ЦЕОЛИТА ПРИРОДНОГО С КРЕМНИЯ ДИОКСИДОМ
}

\author{
В. Д. Рыбачук, Е. А. Рубан \\ Национальный фрармацевтический университет, Харьков \\ v.d.rybachuk@gmail.com
}

Цель работы. Изучить реологические свойства пасты цеолита природного (клиноптилолита) с кремния диоксидом как загустителем для выбора их оптимальных концентраций.

Материалы и методы. Объектами исследования служили модельные композиции паст, содержащих в качестве действующего вещества порошок цеолита природного (клиноптилолит) в концентрациях 15 \%, 20 \%, 25 \% и 30 \%, а в качестве загустителя кремния диоксид в концентрациях 5,0 \%, 6,0 \%, 7,0 \% и 8,0 \%. Определение реологических параметров проводили при температуре $(20 \pm 2){ }^{\circ} \mathrm{C}$ с использованием вискозиметра MYR VR3000 (Испания), принцип работы которого основан на методе Брукфельда. Исследования проводили в диапазоне скоростей сдвига от $1 \mathrm{c}^{-1}$ до $200 \mathrm{c}^{-1}$ с использованием коаксиальных цилиндров.

Результаты и обсуждение. Определено, что исследуемые образцы относятся к тиксотропно-структурированным псевдопластическим системам со структурой коагуляционного типа. Цеолит природный (клиноптилолит) наряду с кремния диоксидом оказывает структурирующее действие на дисперсную систему, а их оптимальные концентрации, обеспечивающие достаточное структурообразование, составляют 25-30 \% и 7-8 \% соответственно.

Вывод. Изучены реологические свойства пасты цеолита природного (клиноптилолита) с кремния диоксидом, выступающем в роли загустителя, и выбраны их оптимальные структурообразующие концентрации. Полученные результаты будут использованы при разработке состава паст энтеросорбентов с цеолитом природным.

Ключевые слова: реологические свойства; цеолит природный; клиноптилолит; кремния диоксид; паста.

\section{RHEOLOGICAL STUDY OF NATURAL ZEOLITE PASTE WITH SILICA DIOXIDE}

\author{
V. D. Rybachuk, O. A. Ruban
}

National University of Pharmacy, Kharkiv

v.d.rybachuk@gmail.com

The aim of the work. Studying the rheological properties of natural zeolite (clinoptilolite) paste with silica dioxide as a thickener, to select their optimal concentrations.

Materials and Methods. The objects of the study were model compositions of pastes containing natural zeolite powder (clinoptilolite) in the concentrations of $15 \%, 20 \%, 25 \%$ and $30 \%$ as the active ingredient, and silica dioxide as a thickener in the concentrations of $5.0 \%, 6.0 \%, 7.0 \%$ and $8.0 \%$. Determination of the rheological parameters was carried out at a temperature of $20 \pm 2{ }^{\circ} \mathrm{C}$ using a MYR VR3000 (Spain) viscometer based on the Brookfield method, studies were carried out in the shear range from $1 \mathrm{~s}^{-1}$ to $200 \mathrm{~s}^{-1}$ using coaxial cylinders.

Results and Discussion. It is determined that the samples under investigation are related to thixotropic-structured pseudoplastic systems with a coagulation-type structure. Natural zeolite (clinoptilolite) along with silica dioxide has a structuring effect on the dispersed system, and their optimal concentrations, providing sufficient structure formation, are $25-30 \%$ and $7-8 \%$ respectively.

Conclusion. The rheological properties of natural zeolite paste (clinoptilolite) with silica dioxide, as a thickening agent, have been studied, and their optimal structure-forming concentrations have been chosen. The results obtained will be used to develop the composition of paste-enterosorbents with natural zeolite.

Key words: rheological properties; natural zeolite; clinoptilolite; silica dioxide; paste.

\section{Список літератури}

1. Орловецька Н. Ф. Паста / Н. Ф. Орловецька // Фармацевтична енциклопедія: вид. 3-тє / під ред. акад. НАНУ Черних В. П. - К.: «Моріон», 2014. - С. 1266.

2. Mezger T. G. The Rheology Handbook / T. G. Mezger. Hanover: Vincentz Network, 2014. - 432 p.

3. Глазкова О. М. Реологія / О. М. Глазкова // Фармацевтична енциклопедія: вид. 3-тє / під ред. акад. НАНУ
Черних В. П. - К. : «Моріон», 2014. - С. 1449-1453.

4. Сравнительные исследования структурно-механических характеристик интраназальных мягких лекарственных фрорм нимодипина / И. О. Рогачев, В. В. Гладышев, Б. С. Бурлака [та ін.] // Запорожский медицинский журнал. -2011. - № 3. - С. 92-94.

5 . Rheological studies of water-ethanol solutions of gel-

ISSN 2312-0967. Pharmaceutical review. 2018. № 1 
Фармацевтична технологія, біофармація, гомеопатія Pharmaceutical technology, biopharmacy, homeopathy

formers / Ie. V. Gladukh, I. M. Grubnik, G. P. Kukhtenko [et al.] // Journal of Chemical and Pharmaceutical Research. - 2015. - No. 4. - P. 729-734.

6. Исследование реологических свойств мягкой назальной лекарственной формы дилтиазема / В. В. Гладышев, Г. К. Кучина, Б. С. Бурлака [та ін.] // Актуальні питання фрармацевтичної і медичної науки та практики. - 2013. - № 1. - C. 69-72.

7. Pharmaceutical preformulation and formulation / M. Gibson (ed.). - NY: Informa Healthcare, 2009. - 533 p..

8. Гладух $€$. В. Реологічні дослідження основи гелю 3 густим екстрактом лопуха / Є. В. Гладух, Сегі Анан Марсель, Н. О. Ніколайчук // Соціальна фрармація в охороні здоров'я. - 2017. - № 3. - С. 21-26.

\section{References}

1. Orlovetska NF. [Paste] Pharmaceutical Encyclopedia: $3^{\text {rd }}$ Edition [Фармацевтична енциклопедія: вид. 3-тє] Kyiv: "Morion"; 2014. Ukrainian.

2. Mezger TG. The rheology handbook. Hanover: Vincentz Network; 2014.

3. Hlazkova OM. [Reologiya]. Pharmaceutical Encyclopedia: $3^{\text {rd }}$ Edition [Фармацевтична енциклопедія: вид. 3-тє] Kyiv: "Morion"; 2014. Ukrainian.

4. Rogachev IO, Gladyshev VV, Burlaka BS, Kechin IL. [Comparative studies of structural-mechanical characteristics of intranasal soft dosage forms of Nimodipin]. Zaporozhskiy med zhurn. 2011;3: 92-4. Russian.

5. Gladukh IeV, Grubnik IM, Kukhtenko GP, Stepsnenko SV. Rheological studies of water-ethanol solutions of gelformers. J of Chem and Pharm Research. 2015;4: 729-34.

6. Gladyshev VV, Kuchina GK, Burlaka BS, Biruk IA. [Investigation of the rheological properties of the soft nasa dosage form of diltiazem]. Aktualni pytannia farmatsevtychnoi i medychnoi nauky ta praktyky. 2013;1: 69-72. Russian. 7. Gibson M. Pharmaceutical preformulation and formulation. NY: Informa Healthcare; 2009.
9. Давтян Л. Л. Реологічні дослідження як основа технологічного процесу у разі створення нового лікарського засобу / Л. Л. Давтян, В. А. Ващук, Ю. П. Поліщук // Фармацевтичний журнал. - 2013. - № 4. - С. 52-58.

10. Рибачук В. Д. Вивчення реологічних властивостей паст цеоліту природного / В. Д. Рибачук, О. А. Рубан // «Укр. журнал КЛМ». - 2016. - № 4. - С. 63-67.

11. Бондарєв $€$. В. Експериментальне обґрунтування використання нового препарату - гранул цеоліту як ентеросорбенту при патології шлунково-кишкового тракту : автореф. дис. на здобуття наук. ступеня канд. фрарамц. наук : спец. 14.03.05 - «фрармакологія» / Є. В. Бондарєв. - Харків, 2005. - 20 с.

8. Hladukh YeV., Sehi AM, Nikolaichuk NO. [Rheological studies of the basis of a gel with a thick bag of burdock]. Sotsialna farmatsiia $v$ okhoroni zdorovia. 2017;3: 21-6. Ukrainian.

9. Davtyan LL, Vashchuk VA, Polishhuk YuP. [Rheological research as the basis of the technological process in the case of the creation of a new medicinal product]. Farmatsevt. zhurn. 2013;4: 52-8. Ukrainian.

10. Rybachuk VD, Ruban OA. [Study of rheological properties of natural zeolite paste]. Ukr. zhurnal KLM. 2016;4: 63-7. Ukrainian.

11. Bondariev YeV. Experimental justification for the use of a new drug - granules of zeolite as an enterosorbent for pathology of the gastrointestinal tract: author's abstract. Thesis for obtaining sciences degree Candidate ща pharm. sciences: speciality 14.03.05 - "Pharmacology" [Експериментальне обгрунтування використання нового препарату - гранул цеоліту як ентеросорбенту при патології шлунково-кишкового тракту: авторефр. дис. на здобуття наук. ступеня канд. фрарамц. наук : спец. 14.03.05 - «фрармакологія»]. Kharkiv; 2005. Ukrainian.

Отримано 03.01.2018 